\title{
Identification of Fluvio-Geomorphological Changes and Bank Line Shifting of River Bhagirathi-Hugli Using Remote Sensing Technique in and Around of Mayapur Nabadwip Area, West Bengal
}

\author{
Sarmistha Mallick \\ Research Scholar, North-Eastern Hill University
}

\begin{abstract}
The present study focuses on the deltaic region of west Bengal, which is one of the most dynamic natural regions of the state. The study area is a part of moribund deltaic region of district Nadia. Bank erosion, channel shifting, siltation of channels, decaying of oxbow lakes are common geomorphic hazards in Bhagirathi- Jalangi interfluve and further south of both of the flood plain of Hugli. The main focus of the study area is to identify the different pattern of fluvio geomorphic features on the flood plain. For the analysis the data on river planform are collected from the survey of India toposheets and a number of satellite imageries. Surveys were carried out to compare the present scenario and the past situation. The analysis reveals that the fluvio geomorphological changes over the period of 45 years are considerably significant. Anthropogenic causes have a greater influence to change the morphology and increases the rate of bank erosion.
\end{abstract}

Keywords: Cut-off meanders, bank line shifting

\section{Introduction}

Rivers are dynamic geomorphological agents showing great deal of diversity in form and behaviour and also in transfer of water and sediment load from land surface to the oceans. Floodplain, sandbars, point bars, riverterraces, cut-off meanders, levees, ox-bow lakes, water bodies, river islands, meander scrolls etc. are unique geomorphic features associated with the middle and lower course of a river that evolve over a significant period of time. Multispectral satellite image of last 40 years provide accurate record of such changes. Visual image interpretation technique helps to extract information and predict overall characteristics and evolution of the terrain associated with these geomorphic features. In the NabadwipMayapur area the river Bhagirathi is jacketing in several places for as thoroughly as possible with earthen embankments on either side. As a result the river can neither throw the load on to the lands adjoining nor carry it fully away with fluctuating flow and current. So bulk of the load settles down in the bed of the river, chokes the channel and raises its floor. When its flood time the river create its own new channel.

\section{Literature Survey}

The Bhagirathi-Hooghly river system is basically a tributary of the main stream of the river Ganga flowing southerly to meet the sea. Hooghly being the lower part of the Bhagirathi - Hooghly river system, the entire river stretch as a whole is christened as Ganga (Banerjee et al 2013). BhagirathiHooghly River system is an essential lifeline for the people of southern West Bengal, which provides abiding supply of water for irrigation and human and industry consumption. The total river reach is experiencing a huge morphometric change followed by lateral shift and bank erosion. The channel has the highest sinuosity and parcels of acute meandering along with the palaeo-channel formations existed on its younger flood plain. Several inter-related effects which influence the distribution of channel migration are: compaction of fine sediment, tectonic movement and channel gradient. The Bengal Basin in the northeastern part of Indian subcontinent, between the Indian Shield and IndoBurman Ranges, comprises three geo-tectonic provinces: (1) The Stable Shelf; (2) The Central Deep Basin and (3) The Chittagong-Tripura Fold Belt. (Laha 2015).Meandering streams are one of the few morphological system for which an abundant historical record exists of changes of channel pattern and associated flood plain erosion and deposition (Panda and Bandyopadhyay, 2010).The river Bhagirarhiis fed from three different sources- Ganga, the spill channels in the east and the rivers from the Chotonagpur Plateau in the west. But unfortunately these sources supply more of sand and silt than water, and so, not only they are silting up the Bhagirathi but they themselves are getting choked up. As a result, the Bhagirathi has turned into a miserably thin remnant rolling aimlessly in the head-water area.

\section{Objectives}

The main objective of this study is to identify the pattern of different fluvio geomorphic features on the flood- plain, including meander cut-offs, oxbow lakes, interscroll swales, back swamp depressions, shallow depressions that hold rain water for an extended period, seasonal water bodies, active channels with considerable variability in turbidity and depth, decayed channels etc. And document their evolution over a period of about 45 years.

\section{Study Area}

The study area is a part of the moribund deltaic region of district Nadia. Here the rivers like Bhagirathi, Bhairab, Jalangi etc. played the most important role in the physical milieu to which human civilization had to adopt. Though the 


\section{International Journal of Science and Research (IJSR) \\ ISSN (Online): 2319-7064 \\ Index Copernicus Value (2013): 6.14 | Impact Factor (2014): 5.611}

land building process has practically ceased and many drainage channels have become functionally inoperative, the hazards of flood are at their highest and the disposal of runoff is a serious concern. Bank erosion, channel shifting, siltation of channels, decaying of oxbow lakes are common geomorphic hazards in Bhagirathi- Jalangi interfluve and further south of both of the flood plain of Hugli. Mayapur and Nabadwip are two world famous pilgrim centers in this catchment. Geographers working in the field believe that the
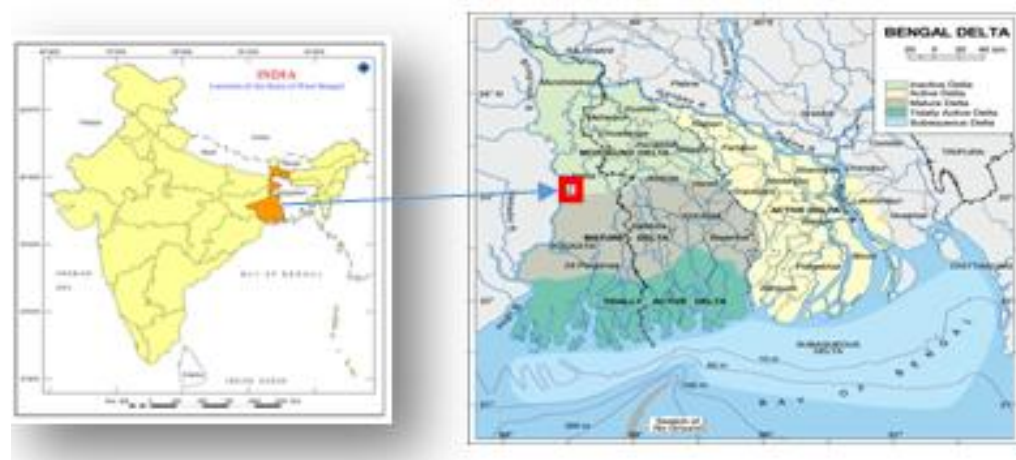

processes of bank erosion, channel shifting, channel sedimentation and decaying of channels in this region are accelerated through the interference of man with nature since this place habituated for more than 400 years. Filed investigation reveals that some of the old settlements referred in ChaitanyaBhagavat of $16^{\text {th }}$ century like Jahanagar, Samudragarh, Nidaya, Ganganagar, MajidihaBhaluka are still in clear existence.
Mayapur is located on the banks of the Ganga River, at the point of its confluence with the Jalangi, near Nabadwip, West Bengal, India,130 km north of Kolkata (Calcutta). The latitudinal and longitudinal value of Mayapur are $23^{\circ} 43^{\prime} 83^{\prime \prime}$ $\mathrm{N}$ and $88^{\circ} 39^{\prime 29 "}$ E. Nabadwip is a city and a municipality in Nadia district in the Indian state of West Bengal. Its name means "9 islands" in the Bengali language. The islands are named Antardwip, Simantadwip, Rudradwip, Madhyadwip, Godrumdwip, Ritudwip, Jahnudwip, Modadrumdwip, and Koladwip. The coordinates of Nabadwipare $23^{\circ} 42^{\prime} \mathrm{N}$ and $88^{\circ} 37^{\prime} \mathrm{E}$. the coordinates of Purbasthali area are $23^{\circ} 25^{\prime} \mathrm{N}$, $88^{\circ} 22^{\prime} \mathrm{E}$ and the coroddinates of Samudragrah are $23^{\circ} 34^{\prime} 66$ " 88³2' 15',

\section{Data Base and Methodology}

Besides old literatures and maps Survey of India Topographical sheets of 1968-69, Landsat MSS image of 1977, Landsat MSS image of 1990, Landsat ETM image of 2014 has been used for the research.

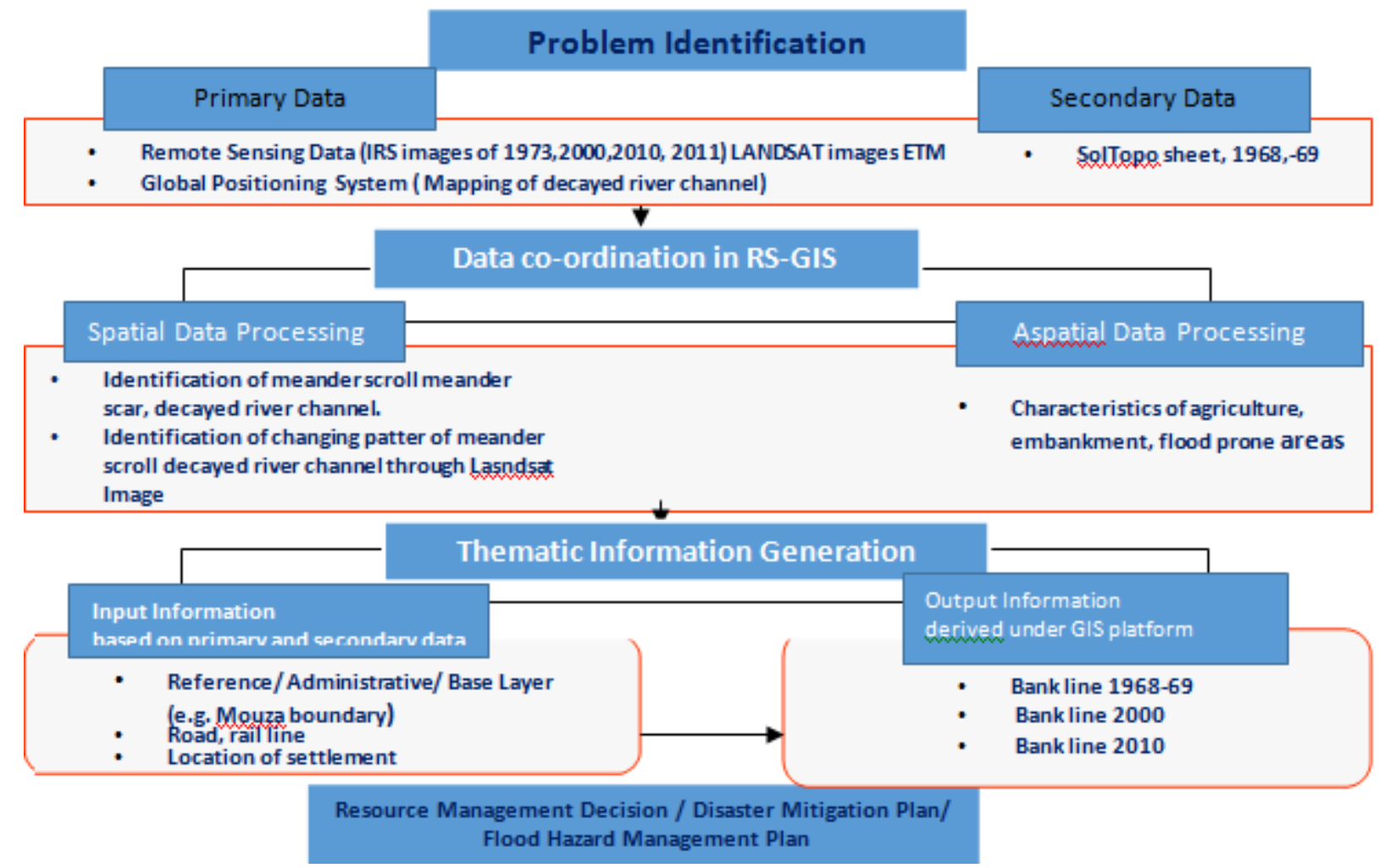




\section{International Journal of Science and Research (IJSR) \\ ISSN (Online): 2319-7064 \\ Index Copernicus Value (2013): 6.14 | Impact Factor (2014): 5.611}

\section{Analysis of Changes}

In the fig 1, Survey of India Toposheet, 1968 vector overlaid on Pan Image 2000 raster, showing the changes of ox-bow lakes and Bhagirathi river courses at Purbasthali between 32 years. River courses in 1968 is represented by deep blue colours and river courses in 2000 represented by Pan Image
(Raster). In fig 2 Survey of India Toposheet, 1968 vector overlaid on Landsat MSS 2010 vector, showing the changes of ox-bow lakes and Bhagirathi river courses at Purbasthali between 42 years. River courses in 1968 is represented by deep blue colours and river courses in 2010 represented by sky colour.

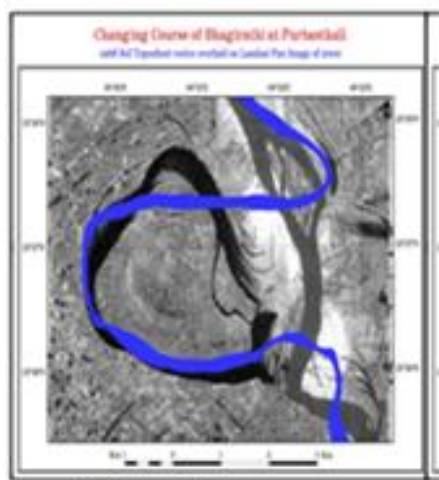

Figure 1

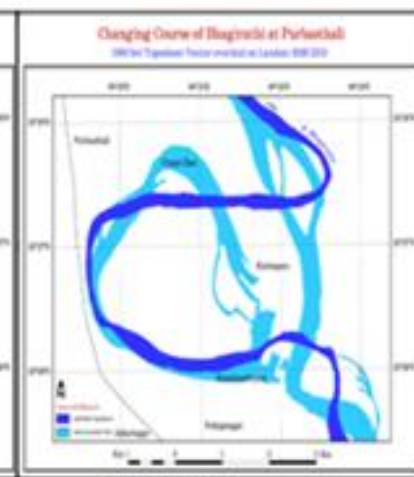

Figure 2

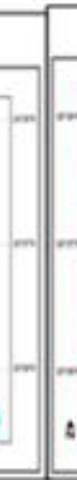

(n)
In fig 3, Survey of India Toposheet, 1968 vector overlaid on Landsat MSS 2010 Raster, showing the changes of ox-bow lakes and Bhagirathi river courses at Purbasthali between 42 years. River courses in 1968 is represented by deep blue colours and river courses in 2010 represented by raster image. In fig 4, Landsat image, 2000 vector overlaid on
Landsat image 2010 vector, showing the changes of ox-bow lakes and Bhagirathi river courses at Purbasthali between 10 years. River courses in 2000 is represented by green colours and river courses in 2010 represented by sky colour.

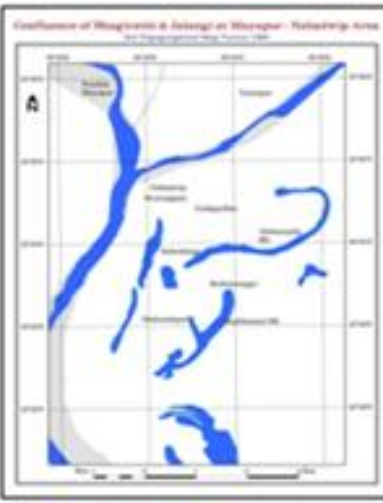

Figure 5

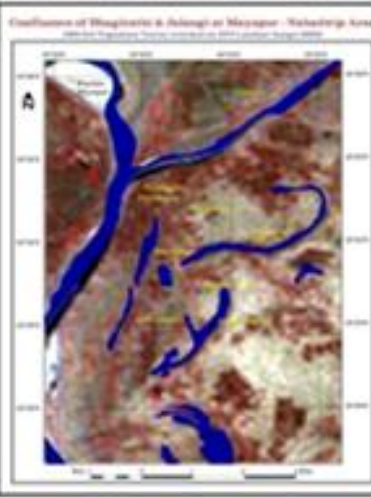

Figure 6

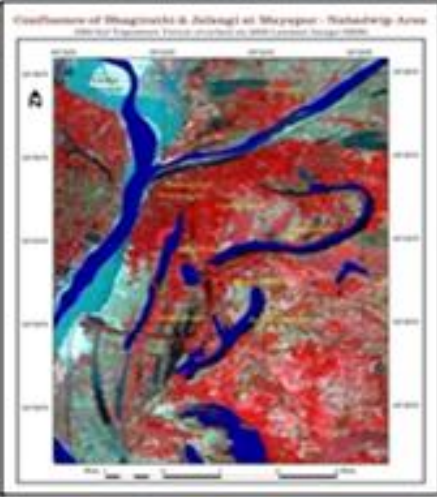

Figure 7

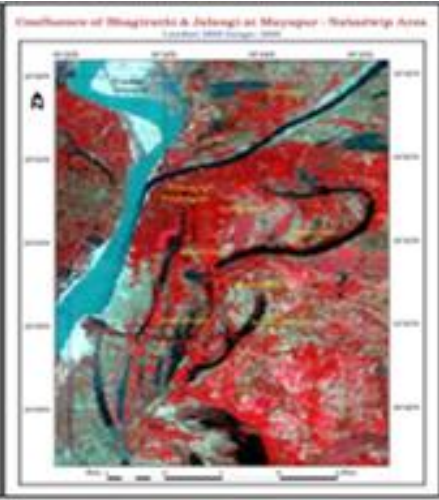

Figure 8
Fig 5 shows the Bhagirathi river courses at Nabadwip areas in 1968 represented by Survey of India Toposheet (vector). In the next fig 6, Survey of India Toposheet, 1968 vector overlaid on Landsat MSS image 1973 Raster, showing the changes of Bhagirathi river courses at Nabadwipareas between 5 years. River courses in 1968 is represented by deep blue colours and river courses in 2010 represented by raster image. In fig7 Survey of India Toposheet, 1968 vector overlaid on Landsat MSS image 2000 Raster, showing the changes of Bhagirathi river courses at Nabadwip areas between 32 years. River courses in 1968 is represented by deep blue colours and river courses in 2010 represented by raster image. Fig 8 shows the Bhagirathi river courses at Nabadwip areas in 2000 represented by Landsat MSS image 2000. 


\section{International Journal of Science and Research (IJSR) ISSN (Online): 2319-7064}

Index Copernicus Value (2013): 6.14 | Impact Factor (2014): 5.611

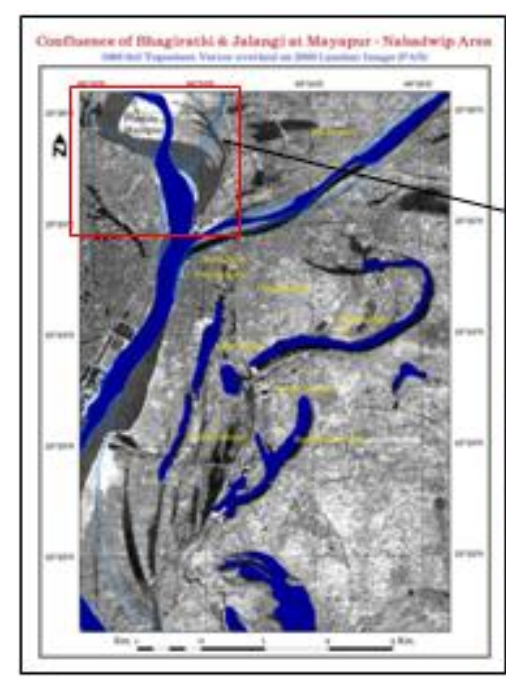

Figure 9

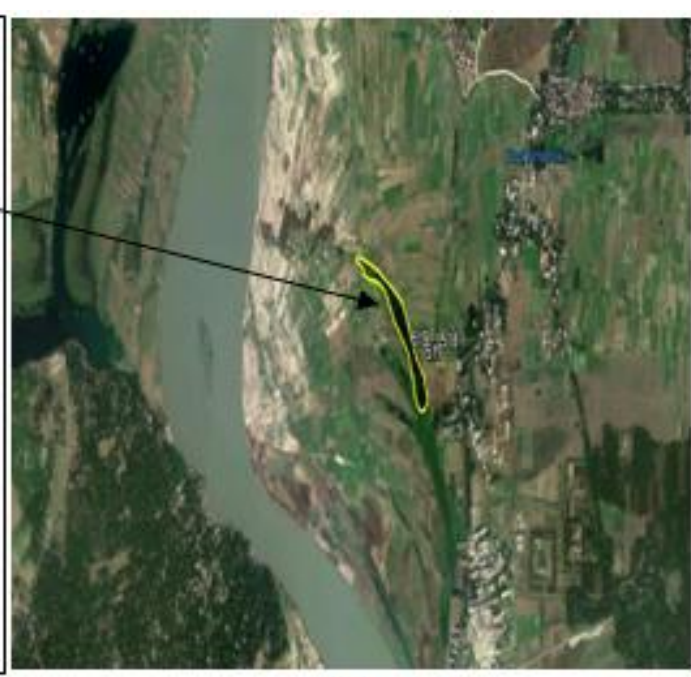

Figure 10

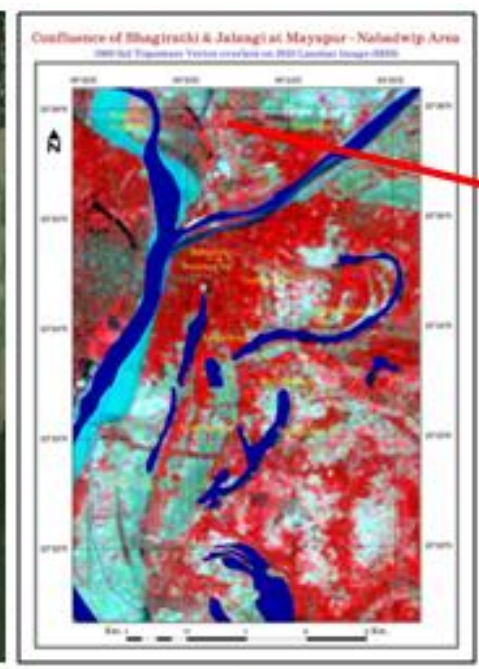

Figure 11
In fig 9 Survey of India Toposheet,1968 vector overlaid on Landsat PAN image 2000 Raster, showing the changes of Bhagirathi river courses at Nabadwip areas between 32 years. River courses in 1968 is represented by deep blue colours and river courses in 2000 represented by raster image. In the next fig 10 which shows the ground truthing of the study area with the help of GPS survey. Though most of the stretch has got decayed only a stretch of $690 \mathrm{~m}$ still consists water and is used for irrigation and fishing .In the last fig 11, Survey of India Toposheet, 1968 vector overlaid on Landsat image (MSS)2010 Raster, showing the changes of Bhagirathi river courses at Nabadwip areas between 42 years. River courses in 1968 is represented by deep blue colours and river courses in 2010 represented by raster image.

The river is jacketed with earthen embankments for more than 100 years on either side the river can neither throw the load on to the lands adjoining nor carry it fully away with fluctuating flow and current. So, bulk of the load settles down in the bed of the river, chokes the channel and raises its floor. Consequently, with fresh deluge from upstream the water level rises too and the jacketing embankment levels have to be raised further in stages. As a result of jacketing the hydraulic pressure steadily increases, enhancing, at the same time the chances of embankment breach and more devastating flood. Secondly, the channels becomes so very much silted up, that the river chooses to break the bank somewhere up the protected zone and shifts to a lowland course charted by itself.

Record of old maps and literatures show that the ancient settlements stays bank on its seat, away from the new shifted channel. Because of vested interest most people cannot move out, but a newer settlement may grow up again on the bank of the new channel. In such shifting the river may, ofcourse, eat away a bank settlement through erosion, when people will try to move lock, stock and barrel. But this is more of an exception than the rule, in most cases the old settlement is judiciously located on a natural levee and the river rather circumvents it in its shifting movement. So the notion that with the shift of a river channel, the settlements in between the two courses are totally wiped out is rather far-fetched. The process of channel shifting and bank erosion is accelerated through the interference of man with the process of nature. Bank erosion is more acute on the bluff side and it accentuates during low water level, when the bank being undercut overhangs, and later collapses with vegetation and structures without warning.

There are innumerable numbers of bills and wetlands locally named "Chakra" (circular or crescentic) shaped water bodies or "Dahas" (muddy marshes) strewn over the entire area. "The rivers have erratic water flow causing floods over large tracts during monsoon, but remains practically dry during summer. The detached lengths of old courses(locally known as moraganga or chara ganga), including ox-bow lakes, meander scrolls, cut offs, bills and other defunct drainages along settlement in and around the study area are used for dumping garbage, defection and dart washing. These also form fishing grounds in the rains and dries up partly during winter to grow crops or weeds. So, these are basically lands which are wet and are neither water body nor waste land.

\section{Conclusion}

In case of Nabadwip and Mayapur, which is situated at the confluence of two major river Bhagirathi and Jalangi the change is quite significant. This places has shown the changes over 400 past years. Nabadwip is the birth place of Sri Chaitanya Dev. The rivers are at a loss to find a perceptible slope and consequently have extremely intricate meandering courses, stagnated or degenerated drainage channels. Identification of fluvio geomorphological changes and proper use of those wetlands, bills,ox bow lakes, meander scroll may provide economical and biological profit for local people. The understanding of the rate of bank line shifting is helpful in proper flood management in this area.

\section{Acknowledgement}

Heart full of gratitude toDr. SumanDe(Sen) Assistant Professor of the Department of Geography, Barrackpore Rastraguru Surendranath College, who has given me valuable suggestions, guidance at every stage of preparation of my paper. I am also grateful to my friends Aparupa Sinha and SubrataMitra for their endless support and help.

\section{Volume 5 Issue 3, March 2016}




\section{References}

[1] Bagchi,K., (1944): The Ganga Delta, University of Calcutta.

[2] Banerjee, A.P., Majumder, A., Dutta, S., (2013): Study on the Ever Changing Physical Regime of the Inner Estuary of the River Hooghly, ARPN Journal of Engineering and Applied Sciences, Vol-8 No-12.

[3] Basu, S.R.,Chakraborty, S.C., (1972): Some considerations on the decay of the Bhagirathi drainage system: The Bhagirathi-Hoogley Basin- edited by KananGopalBagchi.

[4] Bloom, A.L.: Geomorphology, A systematic Analysis of Late Cenozoic landforms( $3^{\text {rd }}$ edition) PHI learning pvt.ltd.

[5] Charlton, R.O., (2009): Fundamentals of Fluvial Geomorphology, Routledge Taylor and Francis group, London and New York.

[6] Chorley, R.J., Schumm, S.A. and Sugden D.E., (1984): Geomorphology, Methuen, London.

[7] Kale, S.B. and Gupta, A., (2001): Introduction to Geomorphology, University press(India) pvt.ltd.

[8] Laha, C., (2015): Oscillation of meandering Bhagirathion the alluvial flood plain of Bengal Basim, Indi: ascontrolled by thrPaleo-geomorphic architecture,International Journal of Geomatics and Geosciences, Vol-5, No-4.

[9] Leopold, L.B., Wolman, M.G. and Miller, J.P., (1964): Fluvial processes in Geomorphology, W.H. Freeman and co. San Francisco.

[10] Morisawa, M., (1985): Rivers. Form and Process. Longman, London.

[11] Morisawa, M., (1968): Streams. Their dynamics and Morphology, Mcgraw Hill book co. New York.

[12] Mukhopadhay, S.C., Dasgupta, A., (2010) River Dynamics of West Bengal(vol-i\& ii), Prayas, Kolkata.

[13] Mukherjee, K.N.,(1996): Agricultural land capability of West Bengal Part-I: West Bengal, pp-13-30.

[14] Panda, S., Bandyopadhyay J., (2011): Morphodynamic Changes of Bhagirathi river at Murshidabad District Using Geoinformatics, Journals of Geographic Information System. Vol 3, pp-85-97.

[15] Rudra, K., (2008): BanglarNodikatha, SahityaSamsad, Kolkata.

[16] Singh, S., (2007): Geomorphology, PrayagPustakBhawan, Allahabad.

[17] Thornbury, W.D., (1960): Principles of Geomorphology, John Wiley and sons. Inc, New York.

[18] Wooldridge, S.W., Morgan, R.S., (1959): An outline of geomorphology, The Physical Basis of Geomorphology, Longmans, London.

\section{Author Profile}

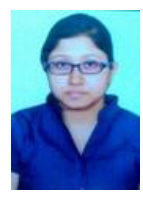

Sarmistha Mallick is Ph.D. Research Scholar, Department of Geography, North Eastern Hill University, Shillong-793022, India 